\title{
ЯЗЫКОЗНАНИЕ
}

\author{
А.А. Рольгайзер
}

\section{ОСОБЕННОСТИ ЯЗЫКОВОЙ КАТЕГОРИЗАЦИИ КОНЦЕПТОВ НЕБЕСНОЙ СФЕРЫ}

Аннотация. В статье описываются основные способы языковой категоризации концептов небесной сферы в русском и французском языках, устанавливаются наиболее продуктивные лексико-грамматические средства, выражающие категории оценки, времени, количества и дименсиональности. Явление категоризации затрагивает все среры и аспекты человеческого бытия. Предмет статьи составляет языковая объективация категориальных признаков, являющихся одним из способов упорядочивания и описания концептуальной картины мира. Объектом исследования послужили концепты небесной сферы, вербализующиеся в лексемах солнце, луна и звёзды.

В ходе исследования используется методика концептуального анализа, заключающаяся в выявлении и описании категориальных признаков, водящих в структуру рассматриваемых концептов, а также метод контекстуального анализа.

Научная новизна работы заключается в установлении категориальных признаков концептов небесной сферы в сопоставительном аспекте применительно к русской и французской лингвокультурам. Основной вывод проведённого исследования сводится к тому, что категоризации является одним из базовых понятий человечества, выступая основным средством систематизации объектов и явлений окружающего мира.

Ключевые слова: категория, категоризация, концепт, признак, когнитивная система, небесные тела, объективация, концептуальный анализ, лингвокультура, картина мира.

Abstract. In this article Rolgayzer describes the main means of the language-related categorization of celestial bodies in the Russian and French languages. The researcher also defines the most efficient lexico-grammatical means that express categories of evaluation, time, amount and dimension. The phenomenon of categorization covers all spheres and aspects of human existence. The subject of the research is the language-related objectivation of category features as one of the ways to order and describe the conceptual picture of the world. The object of the research is celestial bodies concepts verbalized in the form of Sun, Moon and Stars. In the course of the research the author has used the method of the conceptual analysis to define and describe category features constituting the structure of the viewed concepts as well as the method of the contextual analysis. The scientific novelty of the research is caused by the fact that the author defines category features of celestial bodies concepts in terms of Russian and French linguocultures. The main conclusion of the research is that categorization is one of the basic terms of the humanity and the main means of the systematizatino of objects and phenomena in the surrounding world.

Key words: linguoculture, conceptual analysis, objectivization, celestial bodies, cognitive system, characteristic, concept, categorization, category, worldview.

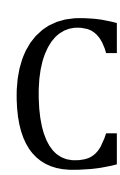

пособность классифицировать предметы и явления окружающего мира по группам, классам и разрядам является важным свойством когнитивной системы человека. Все, существующие в мире объекты, различаются по цвету, размеру, форме и другим категориальным признакам. Категоризация выступает основным способов систематизации знаний в сознании человека.

В кратком словаре когнитивных терминов категоризация понимается как «процесс образования и выделения категорий, членения внешнего и внутреннего мира человека сообразно сущностным характеристикам его функционирования и бытия, упорядоченное представление разнообразных явлений через сведение их к меньшему числу разрядов или объединений» [1, с. 42].

Традиционно, исследователи рассматривают два подхода к категоризации человеческого опыта: традиционный (классический), связывающийся с именем Аристотеля и прототипический (новый) подход [2-6]. Традиционный подход трактует категорию как фиксированный набор значимых признаков, необходимых и достаточных для отнесе- 
ния объекта к определённой категории. Согласно прототипической теории, причисление элемента к некоторой категории происходит на основе его сходства с прототипом - образцовым или наиболее типичным представителем категории [6, с. 249]. Следовательно, прототип представляет собой центр категории, который окружают периферийные элементы, отличающиеся по каким-либо параметрам от наиболее репрезентативных единиц.

Отдельные стороны концептов небесной сферы уже были исследованы и описаны в рамках теории когнитивной лингвистики и линкокультурологии [7-9]. Цель настоящей статьи сводится к анализу способов категоризации объектов небесной сферы (звёзд, луны и солнца) в русском и французском языках.

По мнению М.В. Пименовой, категориальные признаки относятся к группе так называемых базовых признаков, «связанных с мотивирующим признаком и признаками, актуализированными в словарных дефинициях, родовидовыми отношениями» $[10$, с. 114$]$.

В.И. Карасик отмечает, что «категориальные признаки по своей природе представляют собой мощные обобщения предметов, их свойств и отношений. В этом смысле описание категориальных признаков стремится к выявлению языковых универсалий, не общих принципов организации языка, свойственных всем языкам мира, а универсальных понятийных категорий, таких как время, красота, польза, возможность и т.д.» $[11$, с. 210$]$.

В рамках нашего исследования все категориальные признаки мы разделяем на оценочные, временные, квантитативные (количественные) и дименсиональные.

\section{1. Категория оценки}

Когнитивный процесс всегда связан с оценкой предметов и явлений окружающей нас действительности. Всякая оценка основывается на сравнении и выборе того, что признаётся за ценность. Тот, кто даёт оценку, формулирует суждения о привлекательности или непривлекательности, полезности или бесполезности, правильности или неправильности оцениваемого. «Оценка в той же мере относится к области реакций, как и к области стимулов. Она столь же неуловима, сколь и вездесуща» [12, с. 183].

Вслед за Н.Д. Арутюновой, мы разделяем все оценочные значения на два основных типа: общеоценочные и частнооценочные [12, с. 198].

Анализ языкового материала показывает, что общая оценка оказывается не уместной при описании концептов небесной сферы. Прилагательные хороший и плохой не употребляются в описаниях звёзд, луны и солнца. В русском языке чаще всего для этого используется степень сравнения. (И твоё солнце лучше всех солни, я столько на него смеялась! (Л.Н. Андреев. Тот, кто получает пощечины)).

Частная оценка может быть представлена следующими категориями: эстетическая и нормативная. Наиболее частотной является эстетическая оценка (красивый - некрасивый, прекрасный - безобразный). Данная оценка сопряжена с осознанием чувства прекрасного (Так вот, в любое время суток сиротки могли любоваться звездами ... (Е. Хаецкая. Девочки из колодца); Cереndant, en marchant ainsi sous un ciel sans nuages, en admirant les belles étoiles $<$...> il tomba dans une rêverie qui le ramena par degrès à de saines idées de morale. (Balzac. L'Auberge rouge)). Небесные тела на протяжении всей жизни сопровождают человека, привлекают его внимание своей яркостью и загадочностью. Не случайно, в древности люди считали небесные светила драгоценными камнями или предметами, созданными из драгоценных металлов. Отголоски забытых мифов до сих пор существуют в языке в виде стёртых метафор (Золотое солнце поднималось. (К. Букша. Эрнст и Анна); Elle contempla quelque temps les campagnes noyées dans une féerique brume d'argent, le ciel semé d'une poussière d'étoiles diamantées. (G. Le Rouge. Le mysterieux docteur Cornélius)).

Существует мнение, что любая эстетическая оценка лингвокультурно обусловлена. Один и тот же объект в разных национальных культурах может получать различную эстетическую оценку. Данное суждение нельзя отнести к концептам небесной сферы. Языковой материал показывает, что как в русской, так и во французской лингвокультурах звёзды, луна и солнце с точки зрения эстетики оцениваются одинаково. Это объекты, которыми любуются и восхищаются.

В качестве фундаментальной характеристики небесных тел выступает красота. Данный категориальный признак реализуется при помощи прилагательных красивый, прекрасный, прелестный, восхитительный / beau, charmant, magnifique. (Спохватились, что пора домой, только тогда, когда совсем стемнело и большая красивая луна выплыла из-за колокольни. (З.Н. Гиппиус. Смирение); ... de charmantes étoiles scintillent au-dessus de moi, et sablent de leurs paillettes d'or les sinuosités de mon chemin... (Gautier. Mademoiselle de Maupin)). В свою очередь, негативной эстетической оценки в описании рассматриваемых небесных объектов не отмечается.

Категория нормативной оценки сводится к характеристике объекта с точки зрения заданных в обществе стандартов и эталонов. Следовательно, всё то, что отклоняется от нормы, рассматривает- 
ся людьми как необыкновенное и удивительное. (Пять дней над Парижем подымалось необыкновенное солнце. (К.Г. Паустовский. Золотая роза)).

\section{2. Категория времени}

Н.И. Толстой отмечает, что время «универсально прежде всего потому, что имеет внеязыковые, внепсихологические, внечеловеческие основания - оно связано с природой <...> И если замкнутый годовой круг и круг суточный - тоже исключительно природное явление, то деление этих кругов на отрезки времени, на периоды - дело ума, восприятия и опыта человеческого» $[13$, с. 17$]$.

Концепты небесной сферы представлены следующими временными признаками: время жизни, время суток и календарное время.

Анализ признака времени жизни показывает, что небесные тела являются бессмертными субстанциями (...бессмертная луна сияет с темных холодноватых небес, песок в дюнах ледяной. (Л. Петрушевская. Как цветок на заре); Вечно спокойное, бессмертное солнце ярко светило на своём пути к зениту... (С.М. Степняк-Кравчинский. Андрей Кожухов)).

Время «порождено восприятием изменений в мире. Его основной источник - космическое время - смена времён дня и сезонов года» [12, с. 51]. Время возникновения небесных светил на небе выражается в категории времени суток. Наиболее частым временным признаком, описывающим появление луны и звёзд на небе, несомненно, является 'ночь'. Именно в данное время суток рассматриваемые небесные тела царят над землей.

Признак 'утро' приобретает актуальность при описании звезд и солнца (Утреннее солнце выглянуло из-за горы, начало согревать. (В. Ремизов. Воля вольная)). Утренней звездой называют планету Венера, которая утром исчезает последней с небосклона. Когда уже совсем рассветает и исчезают все звезды, Венера ещё ярко светит на небе. (Подслеповато шурилась утренняя звезда над лесом... (В.Я. Шишков. Угрюм-река); Il semblait à ce jeune homme que la plus brillante des étoiles du matin avait été soudain cachée par un nuage. (Balzac. La maison du chat-qui-pelote)).

Категориальный признак 'вечер' актуален для всех рассматриваемых в работе небесных тел. Именно в это время суток звезды и луна сменяют солнце на небосклоне. Своеобразие данного категориального признака выражается с помощью колоративных характеристик. Вечернее солнце отличается от утреннего или дневного и часто описывается посредством следующего синонимического ряда: красный, багровый, пурпурный, пунцовый.
(Пунцовое вечернее солнце било ему в глаза, но он не морщился... (Е. Чижов. Перевод с подстрочника)). Благодаря вариациям цветовых характеристик передаётся большая или меньшая интенсивность солнечного света.

С наступлением темноты на небе появляются первые вечерние звезды, характерной особенностью которых является «бледность». (На небе светились бледные вечерние звёзды. (М.А. Шолохов. Тихий Дон); ... qu'elle pouvait juger à la pale clarté des étoiles... (H. Malot. En famille)).

Небесные объекты могут быть представлены с точки зрения временных сезонов. Зимнее солнце и звёзды наиболее яркие. (Сияли яркие зимние звёзды... (А. Мишарин. Белый, белый день); С улицы в комнату светило яркое зимнее солнце. (Н. Катерли. Всё что угодно)). Им присущ свой особенный холодный цвет. (За окном белое зимнее солнце играло на свежем снегу. (А. Волос. Недвижимость); Синие зимние звёзды, ломаемые морозом, трещали и фосфорились за чёрными окнами. (Катаев. Вещи)).

В весеннее время года солнце, луна и звёзды просыпаются от долгого зимнего сна, обновляясь и радуясь, как и всё живое на земле. (Весеннее солнце пело, обнимая степь. (С. Бабаян. Господа офицеры); Весенняя луна в цветущем саду поднимается каждый вечер теперь... (М.М. Пришвин. Дневники); Так совершаются в природе майские погоды, цветут весенние звёзды... (Н.Г. Помяловский. Мещанское счастье)).

Во французской лингвокультуре признаки времён года не актуальны и представлены единичным примером.

\section{3. Категория квантитативности}

Квантитативные признаки, выражающие количественные характеристики, передаются в языке, как семантическими средствами, так и грамматическими формами [14, с. 10].

При описании звёзд данная категория выражается чаше всего в форме множественного числа. Признак 'множества' в русском языке эксплицируется следующими лексемами: множество, скопище, сонм, миллион, тысяча, безмерное/несметное/ неисчислимое количество, бесчисленность. (Какое безмерное количество звезд смотрит на тебя! (Д. Липскеров. Сорок лет Чанчжоэ)).

Во французском языке выделены следующие конструкции: beaucoup de, un nombre incalculable, innombrable, d'un nombre infini, millier, mille, milliard, en profusion, un tas (...ils virent briller d'innombrables étoiles dans le ciel. (Achard. Envers et contre tous)). Taким образом, звезда и étoile осознаются носителями русского и французского языков как некая совокуп- 
ность светящихся явлений природы, наделяющихся признаком 'множественности'.

В свою очередь солнца и луна являются уникальными объектами, наделёнными признаком единичности.

\section{4. Категория дименсиональности}

Рассмотрим случаи вербализации дименсиональных характеристик небесных тел, а именно признаки веса и размера.

По признаку 'размер' исследуемые концепты могут квалифицироваться как «большие», «крупные», «огромные» или «маленькие». (Утром было большое солнце... (А.П. Платонов. Чевенгур); Огромная луна, всё заливающая призрачным светом, и прохлада ночью. (М. Ходаренок. Зенитные ракетные страсти); На небе высыпали большие и маленькие звёзды. (В. Осеева. Динка прощается с детством)).
Проведённый анализ категориальных признаков позволяет сделать следующие выводы:

1. Категория оценки в русском и французском языках представлена в основном эстетической оценкой. Наряду с этим, русская концептуальная система отличается более разнообразным набором оценочных характеристик.

2. Отличительная черта категория времени - наличием в русском языке способов выражения признаков календарного времени (времени года).

3. Звёзд больше присуща квантитативная категория множественности, в то время как солнце и луна описываются с помощью категории единичности.

4. В сознании носителей сравниваемых языков звезды, солнце и луна могут представляться как 'крупными', так и 'мелкими' небесными объектами.

\section{Список литературы:}

1. Краткий словарь когнитивных терминов / Под общ. ред. Е.С. Кубряковой. М., 1997. 245 с.

2. Боярская Е.Л. Категоризация как базовая когнитивная процедура // Вестник БФУ им. И. Канта. 2011. № 2. С. 18-28.

3. Емельянова Л.Ю. К вопросу о категоризации знаний в языке // Учёные записки РГСУ. 2013. № 3 (116). С. $133-141$.

4. Ма Т.Ю. Классические, прототипические и акцидентные категории // Вестник ННГУ. 2010. № 5-1. С. 373-377.

5. Магировская О.В. Особенности концептуализации и категоризации мира в рамках когнитивной деятельности наблюдателя // Вестник ЧелГУ. 2008. № 21. С. 105-114.

6. Бочкарев А.Е. К проблеме категоризации в теории прототипов: pro et contra // Вестник ННГУ. 2015. № 1. С. $249-254$.

7. Пименова М.В., Балашова Н.П. Соматические метафоры луны в современных поэтических произведениях // Гуманитарный вектор. Серия: Филология, востоковедение. 2015. № 4 (44). С. 32-38.

8. Сидорова Н.П. Сопоставительный анализ структур и способов актуализации русского и английского концептов луна и moon: Автореф. дис. ... канд. филол. наук. Кемерово, 2010. 22 с.

9. Рольгайзер А.А. Концептуальные исследования природного мира (на примере концептов 'звезда' и 'étoile') // Вестник Кемеровского государственного университета. 2013. № 4-1 (56). С. 169-174.

10. Пименова М.В., Кондратьева О.Н. Введение в концептуальные исследования. М.: Флинта, 2011. 176 с.

11. Карасик В.И. Языковой круг: личность, концепты, дискурс. Волгоград: Перемена, 2002. 477 с.

12. Арутюнова Н.Д. Язык и мир человека. 2-е изд., испр. М.: Языки русской культуры, 1999. 896 с.

13. Толстой Н.И. Времени магический круг (по представлениям славян) // Логический анализ языка. Язык и время / Отв. ред. Н.Д. Арутюнова, Т.Е. Янко. М.: Индрик, 1997. С. 17-27.

14. Рольгайзер А.А. Объективация архетипических ментальных образований в русском и французском языках (на примере слов «звезда» и «е́toile»): Автореф. дис. ... канд. филол. наук. Волгоград, 2015. 20 с.

\section{References (transliterated):}

1. Kratkii slovar' kognitivnykh terminov / Pod obshch. red. E.S. Kubryakovoi. M., 1997. 245 s.

2. Boyarskaya E.L. Kategorizatsiya kak bazovaya kognitivnaya protsedura // Vestnik BFU im. I. Kanta. 2011. № 2. S. 18-28.

3. Emel'yanova L.Yu. K voprosu o kategorizatsii znanii v yazyke // Uchenye zapiski RGSU. 2013. № 3 (116). S. 133-141.

4. Ma T.Yu. Klassicheskie, prototipicheskie i aktsidentnye kategorii // Vestnik NNGU. 2010. № 5-1. S. 373-377.

5. Magirovskaya O.V. Osobennosti kontseptualizatsii i kategorizatsii mira v ramkakh kognitivnoi deyatel'nosti nablyudatelya // Vestnik ChelGU. 2008. № 21. S. 105-114.

6. Bochkarev A.E. K probleme kategorizatsii v teorii prototipov: pro et contra // Vestnik NNGU. 2015. № 1. S. $249-254$.

7. Pimenova M.V., Balashova N.P. Somaticheskie metafory luny v sovremennykh poeticheskikh proizvedeniyakh // Gumanitarnyi vektor. Seriya: Filologiya, vostokovedenie. 2015. № 4 (44). S. 32-38.

8. Sidorova N.P. Sopostavitel'nyi analiz struktur i sposobov aktualizatsii russkogo i angliiskogo kontseptov luna i moon: Avtoref. dis. ... kand. filol. nauk. Kemerovo, 2010.22 s.

9. Rol'gaizer A.A. Kontseptual'nye issledovaniya prirodnogo mira (na primere kontseptov 'zvezda' i 'étoile') // Vestnik Kemerovskogo gosudarstvennogo universiteta. 2013. № 4-1 (56). S. 169-174.

10. Pimenova M.V., Kondrat'eva O.N. Vvedenie v kontseptual'nye issledovaniya. M.: Flinta, 2011. $176 \mathrm{s.}$

11. Karasik V.I. Yazykovoi krug: lichnost', kontsepty, diskurs. Volgograd: Peremena, 2002. 477 s.

12. Arutyunova N.D. Yazyk i mir cheloveka. 2-e izd., ispr. M.: Yazyki russkoi kul'tury, 1999. $896 \mathrm{~s}$.

13. Tolstoi N.I. Vremeni magicheskii krug (po predstavleniyam slavyan) // Logicheskii analiz yazyka. Yazyk i vremya / Otv. red. N.D. Arutyunova, T.E. Yanko. M.: Indrik, 1997. S. 17-27.

14. Rol'gaizer A.A. Ob"ektivatsiya arkhetipicheskikh mental'nykh obrazovanii v russkom i frantsuzskom yazykakh (na primere slov «zvezda» i «étoile»): Avtoref. dis. ... kand. filol. nauk. Volgograd, 2015. 20 s. 